\title{
From the logic of ideas to active-matter materialism: Priestley's Lockean problem and early neurophilosophy
}

\section{Charles T. Wolfe}

To cite this article: Charles T. Wolfe (2020) From the logic of ideas to active-matter materialism: Priestley's Lockean problem and early neurophilosophy, Intellectual History Review, 30:1, 31-47, DOI: $10.1080 / 17496977.2020 .1687870$

To link to this article: https://doi.org/10.1080/17496977.2020.1687870

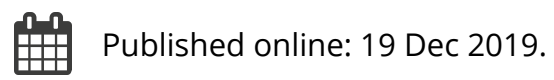

Submit your article to this journal ¿

Q View related articles $\square$

View Crossmark data ¿ 


\title{
From the logic of ideas to active-matter materialism: Priestley's Lockean problem and early neurophilosophy
}

\author{
Charles T. Wolfe \\ ERC EarlyModernCosmology, GA: 725883, DFBC, Ca' Foscari University, Venice, Italy
}

\begin{abstract}
Empiricism is a claim about the contents of the mind: its classic slogan is nihil est in intellectu quod non fuerit in sensu, "there is nothing in the mind (intellect, understanding) which is not first in the senses." As such, it is not a claim about the fundamental nature of the world as material. I focus here on in an instance of what one might term the materialist appropriation of empiricism. One major component in the transition from a purely epistemological claim about the mind and its contents to an ontological claim about the nature of the world is the new focus on brain-mind relations in the eighteenth century. Here I examine a Lockean trajectory as exemplified in Joseph Priestley's 1777 Disquisitions Relating to Matter and Spirit. However, Locke explicitly ruled out that his inquiry into the logic of ideas amounted to a "physical consideration of the mind." What does it mean, then, for Priestley to present himself as continuing a Lockean tradition, while presenting mental processes as tightly identified with "an organical structure such as that of the brain" (although he was not making a strict identity claim as we might understand it, postSmart and Armstrong)? One issue here is that of Priestley's source of "empirical data" regarding the correlation and indeed identification of mental and cerebral processes. David Hartley's theory in his 1749 Observations on Man was, as is well known, republished in abridged form by Priestley, but he discards Hartley's "vibratory neurophysiology" while retaining the associationist framework, although not because he disagreed with the former. Yet Hartley was, at the very least, strongly agnostic about metaphysical issues (and it is difficult to study these authors while bracketing off religious considerations). One could see Locke and Hartley as articulating programs for the study of the mind which were more or less naturalistic (more strongly so in Hartley's case) while avoiding "materialism" per se; in contrast, Priestley bit the (materialist) bullet. In this paper I examine Priestley's appropriation and reconstruction of this "microtradition," while emphasizing its problems.
\end{abstract}

\section{KEYWORDS}

Locke; empiricism; materialism; neurophilosophy; Priestley

\section{Introduction}

My interest in what follows is in an instance of what one might term the materialist appropriation of empiricism. Setting aside recent (and important) revisions to our concept of 
early modern empiricism, which insist we cease to view it as strictly an "epistemological" claim, ${ }^{1}$ if we consider empiricism to be a position (or group of positions) on the mind and its contents, certain eighteenth-century episodes involve a striking transition from apparently "epistemological" claims about the mind to "ontological" claims about the nature of the world. A case in point is the growing focus, in this period, on brain-mind relations. For the study of the mind as a material entity becomes a paramount case of how epistemological issues come to be treated as issues to be resolved by studying the properties of certain arrangements of matter (notably, minds and brains). Elsewhere, I have examined the cases of Diderot and Bonnet in this story of how empiricism is reappropriated. ${ }^{2}$ Here, I focus on a more Lockean trajectory as exemplified in Joseph Priestley's 1777 Disquisitions Relating to Matter and Spirit. Locke, however, explicitly ruled out that his inquiry into the logic of ideas amounted to a "physical consideration of the mind." ${ }^{3}$ What does it mean, then, for Priestley to present himself as continuing a Lockean tradition, while presenting mental processes as tightly identified with "an organical structure such as that of the brain,"4 although he was not making a strict identity claim of, as we might understand it, post-Australian materialism?

Differently put, how does Priestley's cerebral materialism shift the stage from the Lockean treatment of mental life, which he presents as a major source and inspiration of his work (along with the work of Newton and Hartley), given that the Lockean approach explicitly brackets off all physical and specifically cerebral considerations?

First, for purposes of clarification as concerns materialism, I suggest a distinction (which I've elaborated on more elsewhere, as has Falk Wunderlich ${ }^{5}$ ) between two kinds of materialisms - cosmological (or ontological) and psychological - that is, materialism 1 as a claim about the ultimate nature of the world and the entities that populate it, and materialism $_{2}$, a claim about brain-mind identities, which is by no means the invention of adoptive Australian materialists in the 1960s or adoptive Californian neurophilosophers in the 1980s. Now, the latter kind of materialism can seem quite straightforward: it is the identification of brain states and mental states. Lest this sound like an anachronistic, Australian-materialist sort of projection backwards onto early modern texts, consider these statements from John Toland, Anthony Collins, and Priestley, spanning the eighteenth century:

Whatever be the Principle of Thinking in Animals, yet it cannot be perform'd but by the means of the Brain. We Men are conscious of no Thoughts, while the Functions of the Brain are suspended $[\ldots]$ and we observe no signs of Thought in any things that want a Brain. (Toland)

That human consciousness or thinking is a mode of some generical power in matter, will, in my opinion, seem evident to every man that consults his own experience [...] thinking or human consciousness begins, continues and ends, or has generation, succession and corruption like all other modes of matter. (Collins)

I rather think that the whole man is of some uniform composition, and that the property of perception, as well as the other powers that are termed mental, is the result (whether necessary or not) of such an organical structure as that of the brain. (Priestley) ${ }^{6}$

Of course, however, these brain-mind identifications are not all of the same sort. One difference that I find significant is the relation of such claims to a set of purported empirical evidence. Toland and Collins present the identity in very strictly conceptual terms, and 
it's not for lack of possible empirical material (compare the neurophysiologies on offer from Malebranche, the anonymous L'Âme Matérielle, or of course Thomas Willis ${ }^{7}$ ): there was a possible neurophysiology, or indeed, possible neurophysiologies at hand if they had wanted to appeal to them, of which animal spirits is only the best-known case.

Indeed, it can be said of this period, connecting the end of the early modern and the early Enlightenment, that it presents to us early and germinating neurophysiologies and early and germinating materialisms, but the two never meet. The neurophysiologies avoid or are indifferent to fundamental philosophical considerations (Willis seems remarkably unconcerned with the problem of materialism, including when he writes on human and animal souls), and the materialisms seem surprisingly indifferent to neurophysiological "evidence" (Collins, as I mentioned above, is quite able to argue for brain-mind identity without appealing to any empirical evidence; in a kind of "conceptual analysis"). Gary Hatfield's amusing but also precise diagnosis concerning a slightly different period of the Enlightenment seems to apply quite well here:

In the standard narrative, the heroes of the Enlightenment are materialists. If psychology is to be made a science, the story goes, mind must be equated with matter and thereby rendered subject to empirical investigation. The problem is that no one bothered to tell the early practitioners of natural scientific psychology that they had to be materialists in order to be natural scientific psychologists. ${ }^{8}$

A second issue, pertaining more to the issue of philosophical traditions, is the posterity or heritage of Locke; not the Locke of the thinking-matter hypothesis (a more metaphysical problem in which he seems to me to be at least agnostic, although tending towards Nicholas Jolley's reading ${ }^{9}$ ) but the associationist Locke, whose "psychology" was viewed as a highly useful blueprint to be "actualized" or somehow empirically filled out by a variety of first-rank eighteenth-century thinkers, including Hartley, Charles Bonnet, and Priestley. However, Locke might have said: "we have a problem."

\subsection{A Lockean neurophilosophy?}

Locke, as is well known, ruled out quite strongly a reading of his project in terms of a materialist philosophy of mind. He doesn't rule out such an approach as illegitimate or dangerous, but wants it to be understood that such is not the nature of his own project. ${ }^{10}$ Yet a number of authors who one cannot suspect of materialism per se immediately disobey Locke's stricture and seek to put forth naturalized Lockean philosophies of mind - that is, Lockean neurophilosophies of mind with an empirical basis - such as Hartley and Bonnet (who we could describe as sketching out neuropsychologies), or with an additional materialist commitment, such as in Priestley, and (in a more specifically medical context) Le Camus and Cabanis. ${ }^{11}$ Such projects presented themselves as Lockean, yet sought to experimentally investigate the logic and association of ideas, while nevertheless strongly denying that they were materialist projects; unlike Priestley. That is, despite their shared "connexionist" picture of the mind as a system of neural fibers, vibrations, and various versions of identity theories between these systems of resonating parts and the association of ideas, only Priestley is willing to connect such a project to a materialist ontology, connecting the functioning of ideas to a materialist substrate. ${ }^{12}$

What I refer to in the title of this essay as Priestley's "Lockean problem" is just this: how can one extend a model for investigating the mind in a cerebral-materialist direction when 
this model explicitly rejects this possibility? Priestley ignores Locke's strictures against naturalistic explanation and overall ontological commitment, and reconstructs "Locke's system," as he calls it, as a neurophilosophy:

The outlines of Mr Locke's system are that the mind perceives all things that are external to it by means of certain impressions, made upon the organs of sense; that those impressions are conveyed by the nerves to the brain, and from the brain to the mind, where they are called sensations, and when recollected are called ideas. ${ }^{13}$

In other words, for Priestley, "what was essential to the Lockean project [...] was the tracing of ideas to their source in sensation; and David Hartley's Observations on Man showed how this was to be done," 14 although this elegant phrasing leaves out the crucial cerebral-materialist additions that Priestley supplies.

By contrast, Lockean empiricism was in no way either a program for science, an ancillary doorkeeper for a nascent philosophical materialism, or an analysis of the "logic of ideas" which sought to relate their association and general functioning to processes in the brain, as David Hartley notably tried to do in his 1749 Observations on Man with its "vibratory" account of mind, in which small vibrations ("vibrunticles") are impressed in the solid filaments of the nerves by external objects, and these sensations are transmitted by ætherial vibration to the infinitesimal particles that make up the substance of the brain. By their differences in degree, kind, and place, these vibrations represent different primary sensations, or "simple ideas" in the brain, which can become complex ideas through associations with other chains of vibrations. ${ }^{15}$

Priestley was committed to an identity theory of mind and brain as the most fruitful and least costly hypothesis but was also "happy to revise details of his ontology if necessary." ${ }^{\prime 6} \mathrm{He}$ considered that he was carrying on and in some sense actualizing (that is, updating) Lockean psychology:

I flatter myself therefore, that I may be doing some service to future inquirers, by endeavoring to show that this new system has in it as little of truth, as it has of beauty, that we may safely take up the subject, where Locke left it, and proceed to attend to what Dr. Hartley has done by following his steps. ${ }^{17}$

But what then is the empirical basis of Priestley's brain-mind materialism?

\section{Shift towards a Priestleyan cerebral materialism}

\subsection{A vibratory model of mind}

In his 1749 Observations on Man, the Unitarian minister and natural philosopher David Hartley argued that "the uniformity and continuity of the white medullary substance of the brain, spinal marrow, and nerves" ${ }^{18}$ was integral to the transmission of sensory images and the formation of ideas. Priestley famously edited an abridged version of Hartley's Observations in 1775 (of Part I only) and reprinted just those sections of the voluminous book dealing with the association of ideas, excluding all the parts that focus on the mechanics of nervous vibrations and religion (although it is rarely noted that Priestley agreed with the latter; he discarded these portions of the book because he thought they would put off most readers). ${ }^{19}$ 
After briefly crediting Descartes and Locke, Priestley praised Hartley in the following terms, in his Examination of Reid: "Dr. Hartley [...] has thrown more useful light upon the theory of the mind than Newton did upon the theory of the natural world." ${ }^{\text {"O }}$ In the Introduction to the volume of Hartley that he edited, entitled "Hartley's Theory of the Human Mind," as well as in other books published in the 1770s, Priestley defends the idea that the Lockean taxonomy of ideas should be supplemented with the inquiry into its material bases in order to provide a fully fledged explanation of the functioning of men's mind. Thus, he praises Hartley, but he also claims that his thought must be purged from spurious, metaphysical assumptions, chiefly the immateriality of the thinking principle, or mind.

More explicitly, Priestley endorses a Hartleyan vibratory model for neurophilosophy, according to which "The differences of which vibrations affecting the brain are capable are sufficient to correspond to all the differences which we observe in our original ideas or sensations"; ${ }^{21}$ vibrations being distinguishable according to their degree, kind, place, and line of direction, closely following Hartley:

Also, one vibration having been sufficiently impressed, it may be conceived that the region of the brain affected by it will retain a disposition to the same vibrations in presence of others: so that these vibrations may take place from other causes than the original one. ${ }^{22}$

Because the nerves and the brain "are of the same substance, the affection of a nerve during the transmission of a sensation, and the affection of the brain during the perceived presence of it, are probably the same." ${ }^{23}$ Yet Priestley also adopts a deflationary approach to some of Hartley's ontological excesses:

Dr Hartley, who ascribes so much to matter, and so little to any thing immaterial in man (nothing but the faculty of simple perception) yet supposes that there is something intermediate between the soul and the gross body, which he [calls] the infinitesimal elementary body. ${ }^{24}$

Priestley finds this unclear; ${ }^{25}$ the idea of a connection or communication between two substances which have nothing in common is absurd. For him, "the mind is affected in consequence of the affections of the body" just as "the body is liable to be reciprocally affected by the affections of the mind"; "it is one and the same thing that is subject to these affections"; ${ }^{26}$ "the powers of sensation and thought are the necessary result of a particular organization, as that sound is the necessary result of a particular concussion of the air." 27

Hartley himself admits that his adherence to dualism is based on a postulate:

I am reduced to the necessity of making a postulatum at the entrance of my inquiries, which precludes all possibility of proving the materiality of the soul from this theory afterwards.

Thus, I suppose [...] that sensations arise in the soul from the motions excited in the medullary substance of the brain. [...] However, this is not supposing matter to be endued with sensation. $^{28}$

Priestley, revealing himself to be a careful rather than a vulgar neurophilosopher, however, also notes that it is a mistake to assume that the cerebral vibrations are the perceptions by themselves: in addition to the "vibrating power," the brain also possesses a "percipient or sentient power," although at times he presents sentience as simply "arising from" the vibrations (and "the dispositions to vibrate") in the brain. ${ }^{29}$ 


\subsection{Chemical bases for Priestley's materialism}

In the Introduction, Priestley argued that changes in understanding of chemistry meant that far more subtle mechanisms could be used to explain the brain than the simpler hydrostatic models used by early eighteenth-century physicians and philosophers of mind of a materialist bent. ${ }^{30}$ Again, the question of which empirical bases a materialist position is built on, in this period, is significant, as is the related question of the possible coherence between different possible empirical bases (physics, chemistry, the neurophysiology of animal spirits, etc.); this also may remind us of the distinction I suggested at the outset, between ontological and psychological materialism. By the later part of the eighteenth century, important changes in matter theory, in particular Roger Boscovich's analysis of how matter could be construed as an active force as opposed to mere passive extension brought into motion by external causes, made a materialist account of mind all the more viable. For Boscovich, matter consists of points which, in addition to the property of inertia, possess a

mutual active force depending on the distance in such a way that, if the distance is given, both the magnitude \& the direction of this force are given; but if the distance is altered, so also is the force altered; $\&$ if the distance is diminished indefinitely, the force is repulsive, $\&$ in fact also increases indefinitely. ${ }^{31}$

Priestley thought his active-matter materialism was empirically legitimated by Boscovich's definition of matter in terms of force and his rejection of the conception of matter as passive and impenetrable; different empirical bases produce different species of activematter materialism; thus a materialism based on "physics" (vibrations; potentially Newtonian) will be different from one formulating "laws of the mind" (based on the association of ideas; Lockean). Thus he asserted that "matter is not the inert substance that it has been supposed to be"; rather, "powers of attraction and repulsion are necessary to its very being." 32 In other words, whatever we see and experience in the world of everyday life is the result of the activity of material, microscopic particles, the interaction of which is based on forces of attraction and repulsion. Besides Newton's gravity, other powers operate in the microscopic realm and create the cohesion of bigger clusters of material aggregates that appear as impenetrable and inert bodies; inertia is not the defining feature of matter but the superficial appearance of a dynamic subject.

Priestley also considered that his ideas on the brain - which I shall term his "neurophilosophy" as distinct from his specifically conceptual "materialism" - were an extension of his work as a chemist on phlogiston:

My conjecture suggested (whether supported or not) by these facts, is, that animals have a power of converting phlogiston, from the state in which they receive it in their nutriment, into that state in which it is called the electrical fluid; that the brain, besides its other proper uses, is the greatest laboratory and repository for this purpose; that by means of the nerves this great principle, thus exhaled, is directed into the muscles, and forces them to act, in the same manner as they are forced into action when the electrical fluid is thrown into them $a b$ extra. ${ }^{33}$

The new matter theory that Priestley advocated in order to defend his materialist reduction of mental phenomena to modifications of brain substance, in the Disquisitions Relating to Matter and Spirit (1777), involves a re-examination of the fundamental 
features of material particles in order to amend the common conception that they are inert bits of a sluggish substance. He felt that recent scientific discoveries contributed to substantiate the thesis that matter is the subject of active powers and its constituents are not as solid and impenetrable as gross bodies. For instance, electrical phenomena show that matter can be easily penetrated and, thus, the appearance of macroscopic solids must be the result of a force that counterbalances the power of attraction between atoms (if attraction was the only source of the dynamics of penetrable matter, then the universe would collapse in a single point, as Boscovich noted). ${ }^{34}$ One should note here

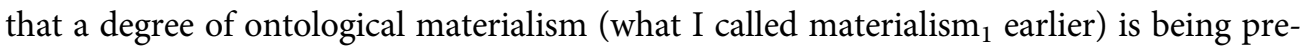
supposed in the psychological (brain-mind) materialism. And, indeed, Priestley himself treated his theory as a newer, updated form of ontological materialism, one in which Hartley and Boscovich's contributions enabled him to move beyond what he called "gross materialism." 35

\subsection{A cerebral materialism}

It is important to see that this neurophilosophy Priestley is sketching out marks a clear shift from Lockean sensationism to a naturalized, indeed cerebralized, model of mind and its ontology. Recall that Locke stated that he would not "meddle" with "physical considerations" about the mind; that is, physiological, neurophysiological, and neuropsychological considerations. Now, the first section of Priestley's Hartley book is a gloss on the nihil est in intellectu quod non fuerit in sensu "slogan" of empiricism ("there is nothing in the mind/understanding which was not first in the senses") and the "sentient principle." ${ }^{36}$ At times, Priestley seems to acknowledge that his approach involves actually displacing Locke's conceptual framework. While Hartley (and, across the Channel, Bonnet, at the same time as Priestley ${ }^{37}$ ) spoke of filling in the blanks left by Locke (which leaves open the perennial question of whether Locke left it that way deliberately or not), Priestley is no longer content to study the relation between sensation and knowledge, or even the "organs of sense" and the mind; he turns his attention away from sensation to the brain:

Afterwards [after a child is as grown up as to be able to inspect his own thinking] he finds that his eye, his ear, and other organs of sense, cannot convey to him the knowledge of any thing, unless there be a communication between these organs and the brain, by means of the nerves; which convinces him that the immediate objects of his thoughts are not in the organs of sense but in the brain, farther than which he is not able to trace any thing. ${ }^{38}$

And

Consequently, if there be no impression upon the brain, there can be no perception in the mind; so that, upon any hypothesis that is consistent with known facts, there can be no state of mind to which there is not a correspondent state of the brain; and, therefore, if the brain itself can be the seat of feeling, or of consciousness, its feeling or consciousness may be just as various and extensive as that of the independent mind itself could be. ${ }^{39}$

\section{Features of Priestley's materialism}

Priestley's materialism is committed to a notion of causal closure; it is "Newtonianfriendly"; it can be described, although the term is not in use in the period (it is generally 
attributed to George Henry Lewes in his comments on John Stuart Mill's System of $\operatorname{Logic}^{40}$ ), as "emergentist"; and it can be described as a "neurophilosophy." As to the first, Priestley's identity claim (about brain and mind) has a distinctive implication of overall "causal closure," which he specifies as follows:

If universal concomitance be the foundation of all our reasoning concerning causes and effects, the organized brain of a man must be deemed to be the proper seat and immediate cause of his sensation and thinking, as much as the inward part of a magnet, whatever that be, is the cause of its power of attracting iron. ${ }^{41}$

Similar passages can be found in Disquisitions and Philosophical Necessity, but here the assumption of constant conjunction as the basis for arguing for a necessary connection between the brain and sensation/thought is stated very clearly. This theory of brainmind identity in necessitarian (or determinist form) not only impacts his understanding of perception, in direct opposition to Reid's, ${ }^{42}$ but also Priestley's general doctrine of determinism (against free will). In his work devoted to this topic, the 1777 Doctrine of Philosophical Necessity Illustrated, motivation is causally bound to action like objects are causally bound to ideas.

Priestley also considers that it is more certain that there are causal relations between matter and mind than that the mind is or is not material ${ }^{43}$ (despite what I've referred to as his ontologisation of Lockean sensationism). His discussion here, however, is also "Newtonian" in several ways. As Alan Tapper has stressed in his work on Priestley, Newton's Rules for Philosophizing play a key role in the core set of arguments in Priestley's Disquisitions: rather than arguing a posteriori from sensations to brain to brain-mind identity, or from the causal closure of the physical world and its implications for mental processes, as he does elsewhere, his real argument is based on Newton's First Rule, which he presents as "We need to admit no more causes of things than are sufficient to explain appearances"; what this yields for his materialism ${ }_{2}$ is that the concept of soul, as it does not explain any appearances, is ontologically redundant. ${ }^{44}$ (This is then a major topic in Reid's critique of Priestley. ${ }^{45}$ )

More distinctively, and building on Anthony Collins' ideas on the issue, Priestley's materialism is emergentist, as he holds that it is not the tiniest particles of matter which can think, but their organized whole: "an organized system, which requires a considerable mass of matter." 46 Priestley writes that

It is true, that it is impossible to divide a sphere so as to make it two spheres; but still the matter of which it consists is strictly speaking, divisible, and the matter of it may be so disunited, that it shall entirely cease to be a sphere. So though that system of intelligence which we call the soul of man, cannot be divided into two systems of intelligence, it may be divided, or dissolved, as to become no system of intelligence at all, ${ }^{47}$

the sphere as a metaphorical way of explaining that the unity of consciousness is no proof for the simplicity of its substance. This is almost exactly an example drawn from Collins contra Clarke (the roundness of the circle does not result from the roundness of its parts, etc.). ${ }^{48}$ Priestley also uses an analogy that would have been familiar to another materialist emergentist whose reflections on the brain are rather close in time to Priestley's (roughly, the 1770s), ${ }^{49}$ namely Diderot, although Priestley takes it from Hartley: 
it may be said, that a whole may have properties which the parts have not, as sound may proceed from the vibration of a string, the component particles of which could not produce any, or as the faculty of thinking may be the result of a certain arrangement of the parts of the brain, which separately have no thought. ${ }^{50}$

This vibrations metaphor was there earlier in the Examination:

The transferring of this comparison to the doctrine of ideas is very easy. If, as Dr Hartley supposes, the nerves and brain be a vibrating substance, the analogy will hold very nearly; all sensations and ideas being vibrations in that substance, and all that is properly unknown in the business being the simple power in the mind to perceive, or be affected by, those vibrations. And if, as Locke and others suppose, matter itself may be indued with that sentient power, even that difficulty $[\ldots]$ is removed. ${ }^{51}$

More specifically,

my idea now is, that sensation and thought do necessarily result from the organization of the brain, when the powers of mere life are given to the system. For I can easily conceive a perfect man to be formed without life, that is, without respiration, or the circulation of the blood, or whatever else it be in which life more properly consists, and consequently without every thing necessarily depending upon life; but I cannot imagine that a human body, completely organized, and having life, would want sensation and thought. This I suppose to follow of course, as much as the circulation of the blood follows respiration. ${ }^{52}$

Overall,

I rather think that the whole man is of some uniform composition, and that the property of perception, as well as the other powers that are termed mental, is the result (whether necessary or not) of such an organical structure as that of the brain. ${ }^{53}$

I have not discussed here the theological dimensions that Priestley brings into play (in keeping with the mortalist materialist tradition in England going back to William Coward and others at the beginning of the eighteenth century). ${ }^{54}$ Suffice to say that, for him, this "organic wholeness" of our being entails "that the whole man becomes extinct at death, and that we have no hope of surviving the grave but what is derived from the scheme of revelation." ${ }^{55}$ Priestley, arguing here in classic materialist ${ }_{2}$ form (like Toland, Collins, and Diderot), but with the explicit language of necessity, declares that he is "equally certain that the brain is necessary to all perception, because if that be disordered, thinking either intirely ceases, or is proportionally disturbed."56

Lastly, one may ask why I anachronistically refer to Priestley as a neurophilosopher, given that it is by no means a term of art of the late-eighteenth century (even if Priestley did emigrate to the United States). It, of course, refers generally to his intention to continue the Hartleyan project of extending a Lockean psychology into the realm of the cerebral. But more than just this general "whiff of the cerebral," one should consider a snide but telling comment of Reid's about Priestley, even if the notorious debate between the two thinkers is not my topic here. Reid described Priestley to Richard Price as "a man who has not yet learned to distinguish Vibrations from Ideas." 57 This claim of a category mistake being made is, of course, a classic, perhaps the classic claim of antireductionists arguing from "the irreducibility of mental experience to the material," targeting any kind of materialist claim (whether eliminativist or reductionist). ${ }^{58}$ 


\section{Conclusion}

One should be clear that (Lockean) thinking matter is not a naturalistic concept that opens onto a comparative, anatomico-functional or physiological study of brain and mind, whether historically - this metaphysical problem was unnecessary or superfluous in the development of such "neurophilosophical" investigations - or philosophically: Locke rules it out. ${ }^{59} \mathrm{I}$ am not downplaying the immense influence Locke's ideas (notably on the issue of thinking matter) had in the eighteenth century, but focusing specifically on what an (unfaithful) Lockean neurophilosophy could have been, and indeed was, in Priestley's hands. Neither Hartley nor Priestley in England, neither Le Camus nor Cabanis in France, were extending Locke's project in a linear fashion, like cutting along dotted lines. Non-naturalistic investigations of the mind like, say, Thomas Reid's are indeed just as much the unfolding of a Lockean study of the "understanding."

Similarly, there is no direct progression in the history of science from Lockean empiricism or forms of eighteenth-century materialism to the emergence of psychology as a scientific discipline in the nineteenth century, not least as most treatises of Psychology or Faculties of the mind (such as Wolff's or Reid's, notably) were not materialist. ${ }^{60}$ Indeed, Reid reconstructed the core Lockean empiricist claim in order to present it pejoratively - as a "neurophilosophical" claim, in which the brain is a source of sensory information. This was definitely not Locke's intention or the content of his empiricism (despite some curious cases in which he slips into the language of animal spirits that went mostly unnoticed, but were spotted by John P. Wright and John Sutton in recent decades), ${ }^{61}$ but it was Priestley's.

What did Priestley invent, in his neurophilosophical way of being unfaithful to Locke? Is it

- a program for a science of mind; or

- a new chapter in (philosophical) materialism?

These are different in an obvious, categorical sense, but the distinction also raises problems for understanding Priestley because, for instance, his argument regarding causal connection between matter and mind is presented as very distinct from the question of the ultimate nature of the mind as material, and this distinction seems to cut across the categorical or disciplinary distinction I suggested. It is difficult to assess Priestley's posterity in this regard because, as Yolton notes, his "fascinating suggestions were not taken up and extended." ${ }^{2}$ When there were increasingly naturalized pneumatologies, psychologies, and otherwise "scientific" (causal, experimental) sciences of mind, they did not particularly seem to draw on Priestley's original and scientifically informed version of a cerebral materialism. ${ }^{63}$ As to his place in a yet-unwritten history of materialism, that is an even more difficult matter, compounded by the fact that materialism is, as Günther Mensching has noted, a "discontinuous tradition." 64

\section{Notes}

1. Haakonssen, "The Idea of Early-modern Philosophy." 
2. Wolfe, "The 'Physiology of the Understanding' and the 'Mechanics of the Soul"; Wolfe, "Materialism and 'the Soft Substance of the Brain'."

3. Essay Concerning Human Understanding, I.i.2

4. Hartley's Theory of the Human Mind, 1775, $\mathrm{xx}$

5. Wolfe, "Materialism"; Wunderlich, "Varieties of Early Modern Materialism."

6. Toland, Letters to Serena, IV, $\$ 7,139$; Collins, A Reply to Mr. Samuel Clarke's Defense of his Letter to Mr. Dodwell (1707), in Clarke, Works, III, 807; Priestley, Hartley's Theory of the Human Mind, xx.

7. Wolfe and van Esveld, "The Material Soul."

8. Hatfield, "Psychology as a Natural Science," 390. He adds that, "In point of fact, of all the major eighteenth century authors who made contributions to the development of psychology, only Erasmus Darwin allowed that mind might be material; nineteenth century founders of psychology, including Wundt, Helmholtz, Lotze, Ebbinghaus, James, Munsterberg, and Binet, banished the very question from scientific psychology" (Hatfield, "Psychology as a Natural Science," 390).

9. Jolley, Locke. His Philosophical Thought; Jolley, Locke's Touchy Subjects. I agree with Jolley (especially in the earlier, more cautious work) that Locke was, at the very least, agnostic as to the possibility of thinking matter and, moreover, that, by even formulating it as a possibility, he was explicitly making a move on the board on which idealism and materialism were in conflict, so to speak. As I seek to show here, this does not mean we should disregard Locke's desire to not be taken to be putting forth a science of the mind. A study of the "understanding" was something different (as Serjeantson also notes, with a different emphasis from mine: Serjeantson, “Human Understanding' and the Genre of Locke’s Essay").

10. "I shall not at present meddle with the physical consideration of the mind; or trouble myself to examine wherein its essence consists; or by what motions of our spirits or alterations of our bodies we come to have any sensation by our organs, or any ideas in our understandings; and whether those ideas do in their formation, any or all of them, depend on matter or not" (Locke, Essay, I.i.2). Although, Locke breaks his own vows when discussing the association of ideas and explicitly explains such mental processes in terms of animal spirits, that is, materially (Locke, Essay, II.xxxiii.6).

11. Rey, "Diderot and the Medicine of the Mind"; Wolfe, "The 'Physiology of the Understanding' and the 'Mechanics of the Soul'."

12. Interestingly, Marx already emphasized the trajectory from Locke to Hartley and Priestley in Die Heilige Familie, drawing on Renouvier, as was noted by Olivier Bloch, "Marx, Renouvier et l'histoire du matérialisme," and more recently reiterated in A. Thomson, Bodies of Thought, vii.

13. Priestley, An Examination, Introduction, 4. To be clear (one anonymous reader found the issue confusing), Priestley doesn't use the term "neurophilosophy" to describe Locke, but I suggest that that is precisely how he reconstructs Locke. As far as I know, the term "neurophilosophy" came into usage with Patricia and Paul Churchland in the 1980s.

14. Harris, Liberty and Necessity, 16.

15. Hartley, Observations on Man, I, 13-16. Hartley cautiously tries to ward off ideological difficulties, adding that "I do not, by ascribing the performance of sensation to vibrations excited in the medullary substance, in the least presume to assert, or intimate, that Matter can be endowed with the power of sensation" (ibid, I, 33). That brain-mind relations and indeed the "identity" between cerebral and mental processes can be fully described mechanistically, "with the same certainty as other effects [ ... ] from their mechanical causes" (ibid, I, 500 ) is nevertheless not, for Hartley, tantamount to an ontological commitment to a materialist "substance metaphysics."

16. Garrett, "Mind and Matter," 191. Further, I should clarify that Priestley's cerebral materialism does not mean that he rejects ontological materialism (as F. Wunderlich notes).

17. Priestley, An Examination, Introduction, 7.

18. Hartley, Observations on Man, I, 16. For discussion, see Thébert, "David Hartley." 
19. He also notes that empirical advances have made the vibratory model seem out of date, but he does not reject it out of hand (Priestley, Hartley's Theory, xviii). Priestley's edition ends with a table of the omitted sections. The only changes he made in what he retained were those necessary for a sense of continuity in the argument. It should be noted that Priestley amassed several volumes of 'facts concerning human nature' intended for a volume illustrating Hartley's theory, but these were destroyed in the Birmingham Riots of 1791 (letter to Theophilus Lindsey, in The Theological and Miscellaneous Works of Joseph Priestley, I, pt. I, 5-6; Webb, "Perspectives on David Hartley," 29).

20. Priestley, An Examination of Dr. Reid's Inquiry into the Human Mind on the Principles of Common Sense, Introduction, 2.

21. Priestley, Hartley's Theory of the Human Mind, xiii. All quotes from Hartley's Theory are from the first of the three introductory essays, thus they are from Priestley, not Hartley.

22. ibid., xv.

23. Priestley, Hartley's Theory of the Human Mind, vii.

24. Priestley, Disquisitions, 79, Priestley's emphasis.

25. Priestley, Disquisitions, 79; Priestley, Hartley's Theory of the Human Mind, xix.

26. Priestley, Disquistions, 28, his emphasis.

27. ibid.

28. Hartley, Observations on Man, I, 511.

29. Respectively, Priestley, Disquistions, 91, and Priestley, Hartley's Theory of the Human Mind, 108 (on memory).

30. Priestley, Hartley's Theory of the Human Mind, xviii. Garrett comments that "Hydrostatics may have been too crude to make materialism compelling, but by midcentury the evidentiary base for materialism had become more viable, as Hartley had shown" (Garrett, "Mind and Matter," 188).

31. Boscovich, Philosophiae naturalis/Natural Philosophy, 16. On the influence of such ideas on Priestley's materialism, see Yolton, Thinking Matter, ch. 6, esp. 110f.; Schofield, The Enlightened Joseph Priestley, 70. The extent of Boscovich's influence on Priestley has been contested (Brock, "Priestley, Enlightened Experimentalist"; cf. Dybikowski, "Priestley, Metaphysician and Philosopher of Religion"); I am not making any strong biographical claim beyond the presence of specifically chemical and "Boscovich-influenced" ideas in the matter theory of the Disquisitions. Now, I take note of Priestley's claim that his materialism was scientifically nourished, but it is possible to take this claim with a grain of salt, if one considers that his arguments are conceptual in nature and (as S. Gino suggests) that the appeals to electricity are primarily analogical. However, my overall emphasis is on the intersection and mutual "contamination" between philosophical materialism and projects for a science of mind, which implies that I am not strictly distinguishing between some "pure" philosophical discourse and some "empirical" scientific discourse.

32. Priestley, Disquisitions, xxxviii; cf. also Priestley, Disquisitions, section II, 11. (Priestley also states that it is because anti-materialists think of matter as passive and inert that they think it is dangerous to attribute intelligence or a mind to it; if matter is recognized as it really is, as active, this objection is dispelled. Thus he can even speak of the "immateriality of matter": Priestley, The History and Present State of Discoveries Relating to Vision, Light, and Colours, 392; thanks to Udo Thiel for this reference.) The first synthesis of these ideas on attraction and repulsion (for which not just Boscovich but also Stephen Hales was a source) was Priestley's History of Optics (1772), and they are a major theme in Priestley, Free Discussion of the Doctrines of Materialism (the exchange with Price). See also Priestley, History and Present State of Electricity.

33. Priestley, Experiments and Observations on Different Kinds of Air, 277-8. It bears noting that this is listed among other "queries," though Priestley arguably believed that the explanation was correct.

34. See the discussion of Priestley in Gino, Medicina e filosofia nell'Illuminismo scozzese. I'm grateful to S. Gino for sharing his work on the topic with me. 
35. Priestley, Disquisitions, 109. He also considers that this "newer" materialism was already espoused by the Church Fathers. "Gross matter" seems to mean the matter of an archmechanist à la Hobbes, inert and passive, whereas more complex concepts of matter involve activity, force, self-organization. In 1775, in his introduction to his (abridged) republication of Hartley's Observations, Priestley describes the "gross and most general" vision of matter as "subject to no laws but those of the five mechanical powers," and he calls this "a turn of thinking that prevailed very much about half a century ago" (Priestley, Hartley's Theory, xviii).

36. Cranefield, "On the Origin of the Phrase nihil est in intellectu."

37. On the different "negotiations" of conceptual and scientific space between empiricism (as a doctrine about the sources of knowledge via the senses) and the duo of neurophilosophy and materialism $_{2}$ (i.e. cerebrally based ontologies of mental life meant either as direct contributions to science or as conceptual facilitations thereof), including in Bonnet, see Wolfe, "The Physiology of the Understanding"; Dupont, Wolfe, and Cherici (eds.) Empirisme et fonctions cérébrales.

38. Priestley, An Examination of Dr. Reid's Inquiry..., lvi-lvii. Antoine Maubec, in Chapter IV of his 1709 work on mental faculties and the brain, the Principes phisiques de la raison, et des passions des hommes, explicitly connects both of these empiricist motifs: he will not assert "anything that is not confirmed by experience or self-evident," and by following this method, he will show that "all of our knowledge comes from sense-impressions." Maubec extends this issue in later chapters (V-VI), describing how in the course of development, sense-impressions imprint themselves on the child's brain as if on a piece of wax.

39. Priestley, Disquisitions Relating to Matter and Spirit, 91. Priestley also argues that, if we consider the principle of thinking as something internal to (but separate from) the brain, this results in a regress, as nothing prevents us from assuming a second principle of thought which resides in the first one, and so on (Priestley, A Free Discussion of the Doctrines of Materialism, 51). He is not always so strict regarding the language of "correspondence," however.

40. McLaughlin, "Vitalism and Emergence."

41. Priestley, A History of Early Opinions concerning Jesus Christ, vol. 1, 84-5.

42. Tapper, "The Beginnings of Priestley's Materialism," 77; Garrett, "In Defense of Elephants."

43. Priestley, An Examination of Reid, Appendix, II, "Of Mr. Harris's Hypothesis Concerning Mind and Ideas," 339.

44. Priestley does not refer in this context to La Mettrie, who argues in just this way about the soul (e.g. in L'Homme-Machine, in La Mettrie, CEuvres philosophiques, vol. 1, 98), but he was a great admirer of d'Holbach (Priestley, Works, IV, 389). He quotes La Mettrie's L'Homme-Machine somewhat oddly as supporting (out of agnosticism) the possibility of immortality, or at least some form of life after death (Priestley, Disquisitions relating to Matter and Spirit, 163); thanks to Pascal Taranto for pointing this out to me.

45. See the analyses of Garrett, Demeter, and Gino.

46. Priestley, Disquisitions, 89

47. Priestley, Disquisitions relating to Matter and Spirit, 86-7.

48. see Collins in Clarke, Works, vol. 3, 859 ff. Priestley's emergentism is crucial in his response to Richard Price in Priestley and Price, A Free Discussion of the Doctrines of Materialism and Philosophical Necessity (e.g. Priestley, Works, IV, 42). Cf. also Martin and Barresi, The Naturalization of the Soul, 132-8.

49. Diderot's "neurophilosophical" reflections on brain, memory, will, and the like are to be found in his unpublished, and perhaps unfinished (it is a matter of specialized scholarly debate), Éléments de physiologie, which he worked on in the 1770s for a number of years. On Diderot's neurophilosophy, see Wolfe, "Materialism and 'the Soft Substance of the Brain"; on the relation between this work of Diderot's and his materialism overall, see Bourdin, "Du Rêve de d'Alembert aux Eléments de physiologie."

50. Priestley, Letters to a Philosophical Unbeliever, 26.

51. Priestley, An Examination, 32. 
52. Priestley, A Free Discussion of the Doctrines of Materialism, 256-7.

53. Priestley, Hartley's Theory of the Human Mind, xx. This was ridiculed by Reid as "Let us suppose with Dr. Priestly that all the Mental Powers of Julius Cæasar resulted from the Organical Structure of his Brain" (Wood, Thomas Reid on the Animate Creation, 134).

54. Thomson, Bodies of Thought; Wunderlich, "Priestley on Materialism and the Essence of God."

55. ibid.

56. Priestley, An Examination of Dr. Reid's Inquiry, 36.

57. Reid to Richard Price, 10 April 1775, quoted by Garrett, "In Defense of Elephants," 138.

58. This distinction, while helpful in a variety of contexts, does not map on to early modern texts very well; it should be used with caution. I found Garrett's suggestions (Garrett, "In Defense of Elephants," esp. 141) very helpful here.

59. John P. Wright does note, however, the influence on Locke of Thomas Willis' lectures on the soul at Oxford, and observes that Willis uses the language of fitly disposed systems of matter (Wright, "Locke, Willis, and the Seventeenth-century Epicurean Soul," 254). However, Wright then notes, consonant with the present essay, that one should not confuse Willis' more "Epicurean" project to naturalize the soul with Locke's rejection of "physical considerations of the mind" (cf. Wolfe and van Esveld, "The Material Soul," 255-6).

60. Schneewind, "The Active Powers." Historians of psychology tend to consider that pneumatology in the eighteenth century was more prominently taught with a commitment to the immateriality of the soul in the background (Thomas Reid being a leading figure here by the end of the century, in the Scottish context), but it was also taught e.g. in Unitarian institutions as a materialist science, or, better put, a science with materialist commitments (here, Priestley is a major figure), as John Barresi has observed (personal discussion). Indeed, both trends can be considered Lockean, not least considering Locke's bracketing-off of a natural science of the mind. Further, Reid had his own neuropsychological concerns, which would make for a different story (see Wood, Thomas Reid on the Animate Creation; Demeter, "Philosophical Methods"; Gino, "Medicina e filosofia nell'Illuminismo scozzese").

61. Wright, "Locke, Willis, and the Seventeenth-century Epicurean Soul”; Sutton, "Carelessness and Inattention."

62. Yolton, Thinking Matter, 124.

63. With the exception of associationist psychology in thinkers such as Mill and Bain. Indeed, as Barresi has noted, there was an "aftermath" of Priestley's project in Thomas Cooper's work on materialism and association psychology, and in Thomas Belsham's "philosophy of mind," based on his pneumatology course at the Unitarian school of Hackney, and Erasmus Darwin, who was followed by William Lawrence. However, according to Reed's From Soul to Mind, this materialist associationist line ended there, with a "victory" for Reid's or Hume's psychology.

64. Mensching, "Le matérialisme," 525, 513.

\section{Acknowledgements}

I thank Sebastiano Gino for his generous assistance with this paper, and John Barresi, Henry Schmidt, and Falk Wunderlich for comments on an earlier draft.

\section{ORCID}

Charles T. Wolfe (D) http://orcid.org/0000-0002-7956-9085 


\section{Notes on contributor}

Charles T. Wolfe is an Assistant Professor (ricercatore) in the Dipartimento di Filosofia e Bene Culturali, Università Ca'Foscari, Venice. He works primarily in history and philosophy of the early modern life sciences, with a particular interest in materialism and vitalism. Recent books: Materialism: A Historico-Philosophical Introduction (Springer, 2016) and La philosophie de la biologie: une histoire du vitalisme (Classiques Garnier, 2019); edited volumes include Monsters and Philosophy (2005), The Body as Object and Instrument of Knowledge (2010, with O. Gal), Vitalism and the scientific image in post-Enlightenment life-science (2013, with S. Normandin), Brain Theory (2014), and Philosophy of Biology before Biology (w. C. Bognon-Küss, 2019). He is co-editor of the book series 'History, Philosophy and Theory of the Life Sciences' (Springer). Papers available at [https://unive.academia.edu/CharlesWolfe]

\section{Bibliography}

Bloch, Olivier. "Marx, Renouvier et l'histoire du matérialisme." La Pensée 191 (1977): 3-42; reprinted in Bloch, Matière à histoires, Paris: J. Vrin, 1998.

Boscovich, Roger. Philosophiae naturalis theoria redacta ad unicam legem virium in natura existentium (1758), translation, A Theory of Natural Philosophy (trans. J.M. Child). Chicago and London: Open Court Publishing, 1922.

Bourdin, Jean-Claude. "Du Rêve de d'Alembert aux Éléments de physiologie. Discours scientifique et discours spéculatif dans Le Rêve de d'Alembert." Recherches sur Diderot et l'Encyclopédie 34 (2003): 45-69.

Brock, W. B. "Priestley, Enlightened Experimentalist." In Joseph Priestley, Scientist, Philosopher, and Theologian, edited by I. Rivers, and D.L. Wykes, 49-79. Oxford: Oxford University Press, 2008.

Clarke, Samuel. The Works of Samuel Clarke, 4 vols (1738). Reprint. New York: Garland, 1978.

Cranefield, P. F. "On the Origin of the Phrase nihil est in intellectu." Journal of the History of Medicine and Allied Sciences 25 (1970): 77-80.

Demeter, T. "Philosophical Methods." In Scottish Philosophy in the Eighteenth Century: Volume II: Mind, Matter, Metaphysics and Method, edited by Aaron Garrett, and James Harris. Oxford: Oxford University Press, forthcoming.

Dupont, Jean-Claude, Charles T. Wolfe, and Céline Cherici, eds. Physique de l'esprit. Empirisme, médecine et cerveau, 1650-1800. Paris: Hermann, forthcoming.

Dybikowski, James. "Joseph Priestley, Metaphysician and Philosopher of Religion." In Joseph Priestley, Scientist, Philosopher, and Theologian, edited by I. Rivers, and D.L. Wykes, 80-112. Oxford: Oxford University Press, 2008.

Garrett, Aaron. "In Defense of Elephants: Priestley on Reid on How to be a Newtonian of the Mind." The Journal of Scottish Philosophy 2, no. 2 (2004): 137-153.

Garrett, Aaron. "Mind and Matter." In The Oxford Handbook of 18th Century British Philosophy, edited by James Harris, 171-193. Oxford: Oxford University Press, 2013.

Gino, Sebastiano. "Medicina e filosofia nell'Illuminismo scozzese: Thomas Reid e la trattatistica fisiologica del Settecento." PhD thesis, Department of Philosophy, University of Turin, 2017.

Haakonssen, Knud. "The Idea of Early-modern Philosophy." In Teaching New Histories of Philosophy, edited by J.B. Schneewind, 99-121. Princeton: University Center for Human Values, 2004.

Harris, James. Of Liberty and Necessity: The Free Will Debate in 18th-Century British Philosophy. Oxford: Oxford University Press, 2005.

Hartley, David. Observations on Man: His Frame, His Duty, and His Expectations. 2 vols. London: Richardson, 1749.

Hatfield, Gary. "Psychology as a Natural Science in the Eighteenth Century." Revue de Synthèse 115 (1994): 375-391.

Jolley, Nicholas. Locke. His Philosophical Thought. Oxford: Oxford University Press, 1999.

Jolley, Nicholas. Locke's Touchy Subjects: Materialism and Immortality. Oxford: Oxford University Press, 2015. 
La Mettrie, Julien Offray de. CEuvres philosophiques, 2 vols. Edited by F. Markovits. Paris: Fayard'Corpus', 1987.

Locke, John. An Essay Concerning Human Understanding. Edited by P. Nidditch. Oxford: Oxford University Press, 1975.

Martin, Raymond, and John Barresi. The Naturalization of the Soul: Self and Personal Identity in the Eighteenth Century. London: Routledge, 1999.

Maubec, Antoine. Principes phisiques de la raison, et des passions des hommes. Paris: B. Girin, 1709. McLaughlin, Brian. "Vitalism and Emergence." In The Cambridge History of Philosophy, 18701945, edited by Thomas Baldwin, 631-639. Cambridge: Cambridge University Press, 2003.

Mensching, Günther. "Le matérialisme, une tradition discontinue." In Materia actuosa ... Mélanges en l'honneur d'Olivier Bloch, edited by M. Benítez, A. McKenna, G. Paganini, and J. Salem, 512525. Paris: H. Champion, 2000.

Priestley, Joseph. Disquisitions Relating to Matter and Spirit. London: J. Johnson, 1777.

Priestley, Joseph. An Examination of Dr. Reid's Inquiry into the Human Mind on the Principles of Common Sense, Dr. Beattie's Essay on the Nature and Immortality of Truth, Dr. Oswald's Appeal to Common Sense in Behalf of Religion. London: J. Johnson, 1774.

Priestley, Joseph. Experiments and Observations on Different Kinds of Air. 2nd ed. London: J. Johnson, 1775.

Priestley, Joseph. Hartley's Theory of the Human Mind, on the Principle of the Association of Ideas, with Essays Relating to the Subject of it. London: J. Johnson, 1775.

Priestley, Joseph. The History and Present State of Discoveries Relating to Vision, Light, and Colours. London: J. Johnson, 1772.

Priestley, Joseph. History and Present State of Electricity, with Original Experiments. London: J. Dodsley, J. Johnson, B. Davenport, and T. Cadell, 1767.

Priestley, Joseph. A History of Early Opinions Concerning Jesus Christ. 1 vol. Birmingham: Pearson and Rollason, 1786.

Priestley, Joseph. Letters to a Philosophical Unbeliever. Bath: R. Cruttwell, 1780.

Priestley, Joseph. The Theological and Miscellaneous Works. Edited by J.T. Rutt, 25 vols. in 26. London, 1817-32; reprint, New York: Kraus Reprint Company, 1972.

Priestley, Joseph, and Richard Price. A Free Discussion of the Doctrines of Materialism and Philosophical Necessity. London: J. Johnson, 1778.

Reed, E. S. From Soul to Mind: The Emergence of Psychology from Erasmus Darwin to William James. New Haven: Yale University Press, 1997.

Rey, Roselyne. "Diderot and the Medicine of the Mind." Graduate Faculty Philosophy Journal 22, no. 1 (2000) (special issue The Renewal of Materialism, ed. C.T. Wolfe): 149-159.

Rivers, Isabel, and Wykes, David L., eds. Joseph Priestley, Scientist, Philosopher, and Theologian. Oxford: Oxford University Press, 2008.

Schneewind, Jerome. "The Active Powers." In The Cambridge History of Eighteenth-century Philosophy, edited by K. Haakonssen, 557-607. Cambridge: Cambridge University Press, 2006.

Schofield, Robert E. The Enlightened Joseph Priestley: A Study of his Life and Work from 1773 to 1804. University Park: Pennsylvania State University Press, 2004.

Serjeantson, Richard W. “Human Understanding' and the Genre of Locke's Essay." Intellectual History Review 18 (2008): 157-171.

Sutton, John. "Carelessness and Inattention: Mind-wandering and the Physiology of Fantasy from Locke to Hume." In The Body as Object and Instrument of Knowledge: Embodied Empiricism in Early Modern Science, edited by C.T. Wolfe, and O. Gal, 243-263. Dordrecht: Springer, 2010.

Tapper, Alan. “The Beginnings of Priestley's Materialism.” Enlightenment and Dissent 1 (1982): $73-$ 82.

Thébert, Angélique. "David Hartley: Vibrations, Associations, Actions.” Dix-huitième Siècle 46 (2014): 417-438.

Thomson, Ann. Bodies of Thought: Science, Religion, and the Soul in the Early Enlightenment. Oxford: Oxford University Press, 2008.

Toland, John. Letters to Serena. London: B. Lintot, 1704.

Webb, R. K. “Perspectives on David Hartley." Enlightenment and Dissent 17 (1998): 17-47. 
Wolfe, Charles T. “Materialism.” In The Routledge Companion to Eighteenth-century Philosophy, edited by Aaron V. Garrett, 90-117. London: Routledge, 2014.

Wolfe, Charles T. “Materialism and 'the Soft Substance of the Brain': Diderot and Plasticity." British Journal for the History of Philosophy 24, no. 5 (2016): 963-982.

Wolfe, Charles T. "The 'Physiology of the Understanding' and the 'Mechanics of the Soul': Reflections on Some Phantom Philosophical Projects." Quaestio 16 (2016): 3-25.

Wolfe, Charles T., and Michaela van Esveld. "The Material Soul: Strategies for Naturalising the Soul in an Early Modern Epicurean Context." In Conjunctions: Body and Mind, Sexuality and Spirit from Plato to Descartes, edited by D. Kambaskovic-Sawers, 371-421. Dordrecht: Springer, 2014.

Wood, P., ed. and intro. Thomas Reid on the Animate Creation: Papers Relating to the Life Sciences. Edinburgh: Edinburgh University Press, 1995.

Wright, John P. "Locke, Willis, and the Seventeenth-century Epicurean Soul." In Atoms, Pneuma, and Tranquillity: Epicurean and Stoic Themes in European Thought, edited by M.J. Osler, 239258. Cambridge: Cambridge University Press, 1991.

Wunderlich, Falk. "Priestley on Materialism and the Essence of God." Intellectual History Review forthcoming.

Wunderlich, Falk. "Varieties of Early Modern Materialism." British Journal for the History of Philosophy 24, no. 5 (2016): 797-813.

Yolton, John W. Thinking Matter: Materialism in Eighteenth-century Britain. Minneapolis: University of Minnesota Press, 1983. 